\title{
Information Exchange and Policy Adoption Decisions In the Context of U.S. State Energy Policy
}

\begin{abstract}
A persistent question in the literature on policy adoption and diffusion focuses on the ways in which jurisdictions gather policy information. Decades of research have offered numerous conclusions regarding knowledge transfer mechanisms assumed to drive diffusion. While important, we suggest that the characteristics of existing work may have limited what we know about the exchange of policy information. Most studies infer learning indirectly and, as a result, the literature has tended to focus on exchange between geographic and ideological peers, to the exclusion of other channels. As an alternative, this study takes a more direct approach and draws on a survey of 112 U.S. expert informants in the area of energy policy. We use the information exchange channels revealed by these informants to predict the diffusion of renewable portfolio standards and electricity deregulation among the American states in order to determine if they offer explanatory leverage beyond the "traditional" channels.
\end{abstract}

Keywords: policy diffusion, information exchange, energy policy, policy adoption

Sanya Carleya,, , Tom P. Evans ${ }^{b}$, David M. Koniskya

a. School of Public and Environmental Affairs, Indiana University

b. Department of Geography, Indiana University

*Corresponding author: scarley@indiana.edu, 812-856-0920

Published version

State Politics \& Policy Quarterly, Vol 18, Issue 2, pp. 122 - 147,

https://doi.org/10.1177/1532440018759466 
Recent advances in the study of policy diffusion have offered tremendous insight into the mechanisms that drive the diffusion process, disentangling "learning"—or the emulation of only successful policies - from the simple imitation of existing innovations or competition between jurisdictions over resources. Interestingly, however, these studies have not made large advances in answering persistent and, in many ways, foundational questions regarding the channels of communication through which policymakers get the information they use when deciding to emulate, imitate, or compete with other states. Over the years, scholars have theorized about a number of these channels, including the exchange of information among neighboring states and ideological peers, through shared professional or associational ties, and via entrepreneurs and interest groups operating in multiple states, among others. However, the relative importance of these myriad channels or the differing patterns of information exchange that they might create has not been resolved empirically.

This lack of resolution is due, in large part, to the fact that the vast majority of studies infer information exchange indirectly by observing the timing of adoptions, similarities between adopting states, and the degree to which the characteristics of a policy in one state predicts subsequent adoptions. Missing from these studies is direct evidence from policymakers regarding the places from which they gather information, and the types of knowledge they seek when considering a policy innovation. Empirically, this has led to a focus on the potential communication channels that are easiest to measure indirectly including the exchange of information among geographic peers and ideologically similar states. These two represent a relatively small fraction of the potential sources of policy information to which states considering an innovation might turn. Recent formal work on diffusion suggests that trying to infer learning from correlations among adopter characteristics can lead researchers to overestimate the importance of external influences on adoption, while missing is the role played by other mechanisms. We argue in this paper that limiting the focus to a small number of sources of policy information not only makes it hard to draw conclusions about the relative importance 
of these in adoption decisions, but may lead us to systematically underestimate the role of external information in the policy diffusion process.

In order to overcome the difficulties created by inferring information exchange from adoption patterns, this study takes a direct approach. Specifically, it makes use of an expert informant research strategy, drawing on an original survey of state legislators and agency officials responsible for crafting and implementing energy policy. These actors were asked which peers they turn to for information regarding energy policy innovation and the reasons why they turn to these states. We then use the information exchange channels revealed by these informants to predict the diffusion of renewable portfolio standards and electricity deregulation, respectively, among the American states. Our objective is to determine if these reported peer relationships offer explanatory leverage above and beyond the "traditional" channels of geographic and ideological peers.

\section{Information Exchange in the Diffusion Literature}

The idea that state policymakers exchange information in the policy diffusion process grows from the earliest work on the diffusion of innovations among individuals, which suggested that the spread of something new is a social process dependent on communication among users and potential users (see Rogers 1995 for a review). Rogers (1969) identified communication channels as one of the four key elements of the diffusion process and emphasized that information about innovations was

most likely to be shared among homophilous networks of individuals. Rogers predicted that the type of communication channel influenced the distribution of adopters. The nature of the communication channels was also a key variable in marketing literature, where it was used to predict the spread and adoption rate of new products (see Bass1969; Mahajan, Muller, and Wind 2000).

Walker (1969) focused the discussion on governments and policy innovations, but maintained the important role of information exchange in the diffusion of innovations. Focusing on the theoretical 
expectation that information was most likely to be shared among homophilous entities, he suggested that state policymakers were most likely to imitate the policy choices of "similar" states. Drawing on strong traditions of regionalism in American politics and political science he surmised that the historical, cultural, and economic similarities between states within the same geographic region would facilitate the exchange of policy information. Other early work similarly concluded that proximity likely facilitated the development of interstate communication networks among policymakers (Crain 1966; Foster 1978).

Scholars have also argued that homophily on a variety of other characteristics likely increases the exchange of policy relevant information among states. It has been consistently argued that shared professional ties among policymakers or administrators can facilitate the transfer of information from one state to another (Walker 1969; Volden 2006). Authors have suggested that similarities among the preferences and characteristics of economic elites may have a larger impact on information exchange than other types of similarity because of the disproportionate influence that group has over policy (Hill and Klarner 2002). Finally, Grossback et al. (2004) argue that policymakers are more likely to seek information from states that are ideologically similar to them, because such states can provide a better sense of whether the outcomes of the policy are likely to match their preferences.

The research on information exchange in the policy process has also moved beyond the concept of homophily to explore other types of communication channels. Walker (1969) himself recognized that "as the American political system has developed, an increasing number of specialized communication systems have been created which cut across traditional regional lines and bring officials from many different regions into contact with each other." He was referring specifically to the importance of what he called "leagues" or suprastate organizations, such as the Council of State Governments, that help communicate innovations to members. Scholars have suggested that states considering policy innovations may gather information—often volunteered to them-from interest 
groups (Balla 2001). Mintrom and Vergari (1998) find that information is transferred when policy entrepreneurs from one state interact with networks of advocates for similar policies across other states.

It is important to note that these discussions of information exchange are, in many ways, independent from the recent focus in the literature on disentangling the mechanisms of diffusion. Channels of communication could be used simply to gain knowledge of policies adopted in other jurisdictions (imitation), to determine the effectiveness of different innovations (learning), or to discover the potential economic consequences of policies adopted in other states (competition). However, the prominence and importance of information exchange in the diffusion process is definitely not independent from the process of internal policy experimentation that recent formal work suggests may be underestimated in typical diffusion studies (Volden, Ting, Carpenter 2011). Indeed, accurately describing the many sources of and motivations for gathering policy relevant information is crucial to understanding the relative importance of external influences on adoption decisions.

\section{Direct versus Indirect Measures of Information Exchange}

In the vast majority of studies, conclusions about the information sources and types of information exchange discussed above have been inferred based on the order and timing of policy adoptions by states. Three models have been primarily used to infer what types of states potential adopters were most likely to look to for information about innovations they were considering. First, if the probability of adoption increases with the proportion of neighboring states that have adopted, then studies conclude that information is being shared among geographically proximal states. Second, if the ideological distance between current and previous adopters is relatively small, studies conclude that states sought policy information from ideologically similar states. Third, if successful policies diffuse more widely than unsuccessful ones, studies conclude that potential adopters "learn" from previous 
adoptions. Very recent work has attempted to create a more comprehensive map of diffusion networks among states (see Desmarais et al. 2015), but these exchange relationships are still inductively inferred from the diffusion patterns of numerous policies.

This indirect method has become the primary way in which information exchange in the diffusion process is understood. The purpose of this paper is not to suggest that the conclusions drawn from this approach are wrong, nor that the methodological techniques used to study this topic are not sophisticated and rigorous. Instead, we suggest that the observational strategy to infer the movement of policy knowledge across states may have focused on an unduly limited set of information exchange channels and could have limited our understanding of this processes by which states observe and learn from each other.

Our empirical strategy for exploring this assertion is relatively straight-forward. We take a direct approach to measuring interstate information exchange in the policy process similar to the one employed by Mintrom and Vergari (1998) almost 20 years ago to understand the role of policy entrepreneurs' network involvement in the successful diffusion of education innovations. In this case, we rely on expert informants from the American states to tell us about the places they look for policy information and the reasons they choose those sources. We then test whether the information exchange channels revealed by those informants help us to more accurately predict the diffusion of renewable portfolio standards and electricity deregulation among the American States.

The renewable portfolio standard (RPS) is a mandate that a percentage of a state's electricity mix must come from renewable resources. These mandates are always specific to a future year, and allow for a gradual ramp-up until the final target is achieved in that final year. For example, California's RPS is a 50\% renewables requirement by 2030. As of 2016, 29 states had an RPS policy and 8 states had a voluntary RPS policy. The adoption of the RPS policy has been studied previously by many scholars, in which some have focused on basic adoption decisions (Lyon and Yin 2010; Matisoff 2008; 
Huang et al., 2007; Chandler 2009), and others on overlapping policies (Yi and Feiock 2012), policy stringency (Carley and Miller 2012), alternative types of peer relationships (Matisoff and Edwards 2014; Nicholson-Crotty and Carley 2015) or the policy process (Carley et al., 2016). The majority of these studies conclude that two of the most important factors for RPS adoption are gross state product and political liberalism. Several have also found that external influences, through either geographic proximity or Walker regions (Walker 1969), help facilitate the adoption of the RPS policy.

Electricity deregulation is a more traditional, market-oriented regulatory policy. Deregulation refers to the conditions that make an electricity market competitive, and not supplied by one single, vertically-integrated company. Rather, in deregulated markets, load serving entities provide distribution services and bill the ratepayer. In full retail choice markets, distribution companies compete for consumer demand and one company serves as the provider of last resort. As of 2016, 17 are considered deregulated electricity market states. The inquiry of policy diffusion and policy learning as it relates to deregulation has not been extensively studied. Those that have published articles on the topic note that deregulation is a particularly compelling area of research due to the rapid rate at which this regulation spread across the American states (Ardoin and Grady 2006), the manner in which deregulation involves intricately both state legislators and state regulators in the decision-making process (Andrews 2000), and the importance of deregulation as the process of establishing a new political order (Meseuger 2005). The results of these studies tend to agree that a high price of electricity is one of the most important factors in influencing deregulatory legislation. Other factors that have been identified as important, but with inconsistent results across these studies, include political leaning and peer influence.

\section{Data and Methodological Approach}


The data that we employ for this analysis come from two separate sources: a survey of state policymakers and implementers, and publicly available state-level data. The survey data were provided by 112 expert informants in the area of energy policy through an online survey administration process. Survey informants included state legislators, bureaucrats, and utility commissioners. A list of potential respondents was first gathered via the internet, in which our objective was to collect an exhaustive list of all public officials that are involved extensively within the energy policy arena. Legislators were drawn from state Senate and House of Representatives websites and selected based on their participation in committees on energy, environment, or natural resources. Bureaucrats were drawn by visiting state energy, environment, or natural resources office websites that were listed on the national association of state energy officials website. Public utility commissioners were identified from the national association of regulatory utility commissioners website. ${ }^{1}$

We solicited participation in our survey from 1,878 respondents; 66 of these original emails were bounced back to us. Of the remaining 1,812 potential respondents, 143 responded to our survey for a response rate of 12.7 percent. Sixteen respondents answered "no" to the two questions asked about direct experience with policy formation or implementation and the survey administration was therefore terminated for these respondents, bringing the total sample to 112. State bureaucrats represent approximately 43 percent of the sample, legislators represent about 40 percent, and utility commissioners made up the last 17 percent. In total, representatives from 46 different states responded to the survey; this accounts for approximately 90 percent of the total U.S. population. We received no responses from individuals in the states of Pennsylvania, Maryland, Arizona, or South Carolina. Since

\footnotetext{
1 The survey instrument was designed by the authors and administered in February through April, 2014. All potential respondents were invited to participate in the survey via email with a link to the survey instrument. Up to three email reminders were sent out to each potential respondent. Surveys were only administered to respondents who answered "yes" to a question that inquired about their direct involvement in energy policy formulation or implementation. The survey instrument was designed to take approximately 20 minutes to complete.
} 
the unit of observation for the survey data is the state level, any respondents from a particular state are combined to represent collectively that state.

The resulting pool of informants has significant insight in this policy area-they hold positions on the legislative committees and in the executive agencies most involved in energy policy in their respective states. About half of the respondents have worked in the field of energy policy for over a decade. Ninety-four percent are involved with at least two energy policy areas, with a majority working in both renewable and more conventional areas. Sixty percent of respondents who completed the personal information section have a graduate degree and more than 95 percent are college educated. The informants are spread relatively evenly across the ideological spectrum, with a slightly higher representation from those that affiliate with liberal politics.

It is important to note that is not a representative, but rather is a purposive, sample of energy policymakers and, as such, we are not using these responses to draw inference about the "typical" channels of information exchange among the states. Instead, we are simply using their responses to develop hypotheses about information exchange relationships that may influence diffusion beyond "traditional" channels. If these hypotheses are empirically verified in analyses of RPS and Deregulation diffusion it may suggest the need to revisit the observational or indirect approach to measuring that concept in future research.

The state-level panel data come from a variety of publicly available datasets, such as the Database for State Incentives for Renewables and Efficiency (DSIRE), the Energy Information Administration (EIA), and the Bureau of Economic Analysis (BEA), among others, as outlined below. These data were gathered in panel format, between the years 1990 and 2013. Depending on the year in which a state served as the first adopter for each policy, we cut the dataset to include only those years 
from first adoption onward. ${ }^{2}$ The dataset used for the RPS policy runs from 1997 through 2013. The dataset used for deregulation runs from 1998 through 2013.

The combined dataset is transformed into dyadic format, which allows us to directly model state pairs. Dyadic data are structured according to dyadic pairs that are composed of all 50 states, and all theoretically possible pair-states, of which there are 49. A dyadic approach is increasingly common for policy diffusion studies (see, e.g., Carley et al. 2016; Volden 2006; Gilardi and Füglister 2008; Gilardi 2012) as an alternative to standard event history analysis because it allows one to directly measure state-by-state influence, rather than a measure of average influence across many states. In a dyadic format, one can measure whether an action such as policy adoption taken in state $_{\mathrm{i}}$ aligns with actions already taken by state $e_{j}$, controlling for relevant characteristics in both statei and state $\mathrm{j}_{\mathrm{j}}$. This is in contrast to the typical event history analysis approach, in which state $e_{i}$ might act in a way that aligns with $\sum_{j=1}^{N}$ Actionj $/ N$, where $j$ represents the number of states. $N$ might include all of the other 49 states, or may include a specific subset of states, such as those within a certain geographic proximity.

We apply three corrections to the data, as is standard for this type of analysis. The first requires that we drop the initial adopter of each policy since, presumably, this state initiated the policy diffusion process not based on any other states' experiences. For the RPS policy, we drop Massachusetts and Nevada, both of which began their RPS policies in 1997. In keeping with others' practices (Carley et al., 2016), we also drop Iowa from the sample. Iowa adopted a policy in 1983 that resembled modern RPS policies but with important differences. For deregulation, we drop California, Rhode Island, and Massachusetts, all of which deregulated their electricity markets starting in the year 1998. The second correction, referred to as the Boehmke correction (2009), removes the potential source of bias that

\footnotetext{
${ }^{2}$ It is important to note that there is a slight difference between the RPS and deregulation in terms of date of adoption (i.e., when the policy becomes effective and enforceable) versus date at which the diffusion process may begin. For the RPS policy, the date of adoption of the policy is either the same as or one year off from when the legislation passed. For deregulation, there is often a longer lag of up to a year or several years between when the legislation passed and when it became effective and enforceable.
} 
might arise if we falsely measure the opportunity for one state to emulate another. With this correction, we only include dyads in the model once one of the states in the pair has adopted the policy and thus allows the other state the opportunity to emulate. The third correction is standard for event history analysis studies, in which we drop the dyad from the analysis once both states that comprise the pair adopt the policy. The estimation model that we employ is a probit maximum likelihood estimation with clustered standard errors on the dyadic pair.

In order to identify information exchange channels we focus heavily on responses to two questions from our survey. The first question asks "When legislators in your state consider adopting an energy policy, which other states do they turn to for information to help inform the decision?” Respondents were allowed to identify as many sources as they wanted from a menu of all 50 states. These responses compose the energy policy information dyads of our analysis and the structure of the social network of our sample.

The second question asks "Why do you or your colleagues in your state look to [each state selected in the first question] to inform energy policy decisions?" Possible response categories included similar economic make-up, similar energy markets or resources, similar government or citizen ideology, neighboring states, regional states, traditional relationships, similar interest group influence, attend the same conferences or professional meetings. There was also an "other" category, which produced a variety of responses, as discussed below. Table 1 summarizes the responses for these questions. As the table suggests, traditional explanations including geographic and ideological proximity are among the most frequent reasons why these informants believe their state looks to another for policy information, but those reasons accounted for just over $40 \%$ of the reported reasons.

[Insert Table 1 about here]

We provide a set of calculations in Table 2 that address to two possible concerns that one could raise about our sample: 1) with a lower response rate than is ideal, how can one ensure that those states 
mentioned as peers by participating experts are not idiosyncratic; and 2) is it possible that different types of policy experts list systematically different peer relationships? We explore these questions through measures of inter-, intra-, and overall overlap among the responses, broken down by state. In Table X, we first list the number of informants overall, and then the number of agency and legislative informants, respectively. We then show the average number of relationships by each type of informant. Here, we see that, on average, bureaucratic respondents reported more peer relationships (average of 4.0 per state) than legislative informants (average of 2.2 per state). This difference is statistically significant, based on a two-sided t-test (not shown). The next two columns in the table show the total number of peer relationships without accounting for overlapping responses, as well as the total number with accounting for overlap. These two columns demonstrate that there is decent overlap in responses, a finding that is reaffirmed by the intra-, inter-, and overall measures of overlap in the remaining columns of the table. Approximately 30\% of all peer relationships noted by one type of respondent were also noted by the other. The intra-overlap within both respondent categories, respectively, is about $40 \%$; that is, about $40 \%$ of all respondents noted by a legislator were also noted by another legislator. The final column combines the inter- and intra-overlap measures into one overall measure of overlap. We see here that approximately $50 \%$ of all reported peers were noted by more than one state respondent. We believe these estimates to be fairly high, and to provide at least some evidence that reported relationships were fairly consistent, both within and across respondent categories.

[Table 2 about here]

\section{Variables}

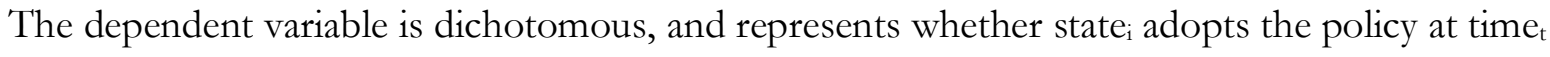
if state $_{j}$ already had the policy in time $\mathrm{t}_{\mathrm{t}-1}$. The RPS policy is also considered adopted even for those states that choose to make compliance with the policy voluntary, as is standard in the policy diffusion literature (see, e.g., Tews 2003). The deregulation variable is considered present for those states and 
years in which the market was either partially or full deregulated. The source of the RPS data is the DSIRE (NC Clean Energy Technology Center 2015). The source of the deregulation data is the EIA (2010), as well as several state statutes that we referenced to confirm the years in which deregulation began and, in some cases, ended. ${ }^{3}$

Our primary independent variables of interest all measure peer relationships. The first two measure the "traditional" exchange channel. The first of these is neighbors, where all dyads that share a contiguous border are coded as one, and all others coded as zero. The second is ideological similarity, which we measure as the absolute distance between state ${ }_{i}$ and state on the Berry et al. measure of government ideology.

All of the other peer relationship variables come from the survey data, as described above. Each variable represents a different reason that state looks to state $_{j}$, based on the information provided by our state representative respondents. For every dyad in which state $\mathrm{i}_{\mathrm{i}}$ reported a specific relationship with state , the variable equals one. ${ }^{4}$ In addition to the response categories discussed above, we also create an indicator coded 1 for any information exchange channel other that geographic or ideological proximity. All reported relationships between pairs are coded to persist through the entire dataset; that is, these peer relationship variables are considered time-invariant. ${ }^{5}$

\footnotetext{
${ }^{3}$ In those cases where a state deregulated or partially deregulated its electricity sector, but the suspended or reversed the process in subsequent years, we still include these states as adopters in our analysis. Subsequent changes are not captured.

${ }^{4}$ As noted above, all responses from the same state are aggregated to represent just one value for the state as a whole. If, for example, someone from California reported that the state looks to New York and another respondent from California reported that the state looks to Massachusetts, then we document that as California has a peer relationship with both New York and Massachusetts. For the regression analysis, we did not double count, or double weight, responses when two respondents or more gave the same answer. So, returning to the example above, if both respondents reported that California has a relationship with New York, we still only code the relationship between California, state ${ }_{i}$, and New York, state $\mathrm{j}$, with a one.

${ }^{5}$ We make this assumption in part because we have to, given that we only surveyed informants at one point in time. However, we believe that this decision is supportable for a number of reasons. First, the instrument explicitly asked respondents to think about historical relationships with other states when answering questions. Second, respondents report more than 10 years of involvement with energy policy decisions in their states on average; so we expect that their recollections typically cover much of the study period.
} 
We also include control variables that resemble those used in other renewable energy policy (Carley and Miller 2012; Matisoff 2008; Lyon and Yin 2010; Yi and Feiock 2012; Schaffer and Bernauer 2014) and deregulation (Ardoin and Grady 2006; others) diffusion studies. The first is a measure carbon dioxide $\left(\mathrm{CO}_{2}\right)$ emissions per state capita (EPA 2010) as a measure of the fossil fuel industry's interest group strength. The second control is the average real state price of electricity (U.S. EIA 2015). We also include measures of citizen and government ideology, respectively, taken from Barry et al. (2010). The final control is a time-invariant measure of total state renewable energy potential from both solar and wind energy, as measured in GWh per year. Wind potential is based on available windy land area with a capacity factor of 30 percent at a height of 80 meters above ground (DOE 2011). Solar potential is based on average solar radiation measured from 1961-1990 for a south-facing flat-plat collector with zero degree tilt (NREL 1991). This estimate is then multiplied by the total area of the state and the average number of sunny days per year. Finally, we include year splines in order to account for the differential probability of adopting these policies over the study period.

\section{Results}

Findings from models using the information exchange channels described above to predict actual energy policy adoptions are presented in Table 2 and 3 . The first analyzes the adoption of renewable portfolio standards between 1997 and 2013. The base model, which approximates a "traditional" diffusion study, is presented in the first column. Consistent with previous studies of RPS adoption, the model suggests that more liberal states, as well as those with deregulated electricity markets and more potential for renewable energy production, were more likely to adopt these policies. Alternatively, higher electricity prices and a stronger fossil fuel industry correlate negatively with adoption. In terms of the diffusion variable, the results are again similar to those produced by prior studies and suggest that states are more likely to emulate adoption in another state if that state is a 
neighbor or if it is ideologically similar. Substantively, these effects are quite large, with geographic proximity increasing the predicted probability of policy emulation by 0.11 and ideological similarity increasing it by 0.12 .

The real variables of interest are the nine channels of information exchange identified by our expert informants and the 1 indicator we create for any nontraditional exchange channel, presented in the remaining columns. At first, we can note that six of these are significantly related to the likelihood of RPS adoption despite the presence of controls for geographic and ideological proximity. The combined indicator is also significantly related to the probability of adopting the policy of the dyadic partner. In all these cases, the substantive impact is also quite significant. For example, if an informant

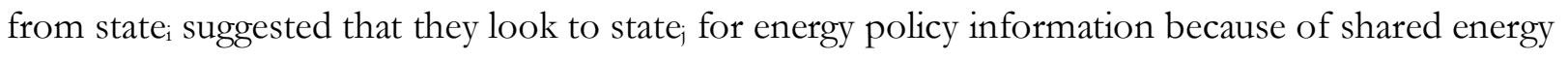
resources or markets, the former had a 0.05 higher probability of emulating an RPS adoption in the latter. When the informant said that their state looked to another for information because it was considered it ideologically similar, that probability increased to 0.12. Again, it is important to remember that we observe this result even in the presence of a significant control for the difference between the two states empirically estimated ideology scores. Sharing information regarding energy policy because the informant identified another state as a regional peer translated into an increase of 0.07 in the probability that the informant's state emulated that other state's RPS policy. Finally, we can note that having a "traditional" relationship with another state, which includes historical connections for any number of reasons that do not have to be policy specific, increased the probability that state would emulate statej's policy by 0.06 .

\section{[Insert Table 2 About Here]}

While the independent impacts of these alternative information exchange channels are interesting and germane to our first research question, we are also interested in the degree to which traditional learning channels serve as blunt proxies for these more precise exchange relationships. The 
most direct way to do this is to examine the degree to which things such as "shared energy markets" mediate the impact of measures of geographic and ideological proximity. Looking across the models in Table 5, the first thing to note is that the variables measuring alternative information exchange channels primarily affect the size of the coefficient for the measure of neighbors. The one exception to this, unsurprisingly, is the impact of reported ideological similarity on the effect size for our calculated measure of ideological proximity. Substantively, the results suggest that about $8 \%$ of the impact attributed to geographic proximity in the base model is actually due to shared energy resources or markets. The impact of being a neighbor on the likelihood of RPS emulation drops by $12 \%$ when we account for an informant's description of a "traditional" relationship between two states. Finally, it appears that approximately $8 \%$ of the impact attributed to the neighbors variable is a result of shared interest group influence.

The results from the models of electricity deregulation diffusion, presented in Table 6, produce surprisingly similar results to the RPS diffusion models, despite the very different character of these policies. Beginning with the base model, the findings suggest that states were more likely to emulate the deregulation of neighboring states and of those that were closer to them ideologically. Despite the presence of these traditional controls, however, 5 of the 6 channels of information exchange that were associated with RPS adoption also correlate with electricity market deregulation. The indicator of any nontraditional reason is also a significant predictor of adopting electricity deregulation. Sharing energy markets or resources increased the probability that state $e_{i}$ emulated deregulation in state by $^{0} 0.04$. Perceived ideological similarity had a similar impact. States had a 0.03 higher probability of emulating deregulation policy in states where informants suggested a traditional relationship existed or in those identified as regional peers. Shared interest group influence had the largest effect on the deregulation,

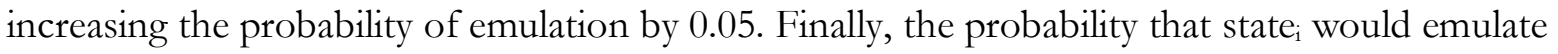




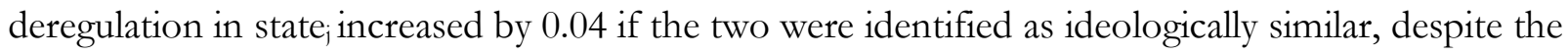
presence of a calculated measure of ideological distance between the two states.

[Insert Table 3 Here]

As in the case of RPS adoptions, the channels of information exchange identified by our expert informants mediate the impact of measures of geographic and ideological proximity. Substantively, the results suggest that between 9 and 10\% of the effect on adoption attributed to being a neighbor in the base model is actually the result of shared energy markets, regional proximity, a traditional relationship, or shared interest group influence. If an informant identifies another state as ideologically similar is reduces the impact of the calculated measure of proximity by $10 \%$.

\section{Discussion and Conclusions}

The results discussed above suggest some important insights into the policy diffusion process. Expert informants suggest that their states look to other states for energy policy information for numerous reasons, and that these reasons are only partially captured by the traditional variables that diffusion studies use to proxy information exchange. The most important thing about these alternative policy learning paths is that they predict actual policy emulation decisions. Even in the presence of highly significant controls for whether two states share a border and the ideological distance between them, our models consistently show that other reasons for sharing information — such as shared energy markets, similar interest group environments, or just having an enduring relationship—increase the probability that one state will emulate the policy adopted in another.

In addition to this independent impact, the paths of information exchange identified by expert informants often mediate the effect of traditional proxies, particularly when it comes to geographic proximity. This implies, as scholars of diffusion have long argued, that it is not really sharing a border that matters in the diffusion process, but rather the similarities and relationships that the border 
represents. Our results provide some of the first empirical information about the precise reasons for information exchange that are captures in the variable "neighbors."

The independent and mediating effects of the information exchange pathways in our empirical models in relation to the traditional measures that diffusion studies use to capture them invite some additional investigation. For example, having a "traditional" relationship significantly increases the probability that state ${ }_{i}$ will emulate RPS or electricity deregulation in state. It might be easy to assume that that result is due in large part to the overlap between geographic proximity and the likelihood of having such a relationship. Interestingly, however, the correlation between the identification of a traditional relationship and actually sharing a border is relatively low $(0.54) .{ }^{6}$ Examining the individual responses, we see that states do sometimes identify neighbors as those with which they share a traditional relationship, but that they are equally likely to identify a state with which they do not share a border. As an example, informants from Delaware reported that they have looked to New Jersey for energy policy because the two states share a "traditional" relationship, but they also suggested that their state had a similar relationship with California. Similarly, policy experts in Colorado exchange energy policy information with New Mexico and Utah because of traditional ties, but they also report looking to Minnesota and Oklahoma for the same reason.

The fact that the alternative reasons for policy information exchange reported by informants are both distinct from and overlapping with traditional measures, such as geographic proximity, becomes even clearer if we use an interaction term to distinguish between these things empirically. Table A1 in the Appendix includes an interaction between the indicator of neighbors and the indicator of sharing a traditional relationship. The results suggest that the impact of having such a relationship on the likelihood that state ${ }_{i}$ will emulate the RPS policy of state ${ }_{j}$ is substantially larger when the two states do not share a border.

\footnotetext{
${ }^{6}$ We generate rho using polychoric principal components analysis because both measures are dichotomous.
} 
We can also gain some additional insights by more closely examining the impact of ideological similarities in our empirical models. In the case of both RPS and deregulation, reported ideological similarity as a reason for information exchange substantially increased the probability of policy emulation between states. The impact was as large as the measure of ideological proximity that we calculate using the Berry et al. scores, which we also controlled for in these models. The reason for this somewhat surprising result is revealed through an examination of the survey responses. The absolute ideological distance in the calculated measure ranges from 0 to 93 , but in $80 \%$ of the cases where an informant listed ideological similarity as a reason for an information exchange the average calculated distance between the pair of states was less than 12. This suggests that when states use ideological similarity as an information shortcut, as the bulk of recent diffusion scholarship suggests that they do, they are actually looking primarily to states that are very, rather than just somewhat, similar.

The consistency of the findings across two policy areas is a final point that invites discussion. The survey administered to these experts actually contained a question asking them to identify the particular area of energy policy in which they worked. To our surprise, many respondents did not answer this question directly but instead wrote in that it was unrealistic to expect that someone would focus primarily on renewables policy or on unconventional natural gas production or on traditional oil and gas extraction. Instead, they suggested that energy policy experts work across multiple areas, implying that the information exchange channels that they identified among states were also not policy specific.

The results from our empirical analysis seem to bear this out. With the exception of regularly attending the same conferences, the other reasons for seeking information predicted the likelihood of policy emulation between states for both RPS and electricity deregulation. These are very distinct policies for a number of reasons. The first diffused quite widely in a traditional s-shaped pattern, while the other spread to a smaller number of states much more quickly in a rapid diffusion pattern (see 
Nicholson-Crotty 2009; Boushey 2010). The policies have different very different goals regarding outcomes, are supported by different interest groups, and have engendered different levels of controversy during the diffusion periods. In other words, they are very different from one another, and yet, the information exchange channels identified by state-level experts predict the adoption of each fairly consistently. This suggests to us that these pathways for learning may transcend specific policies, at least in this area. 


\section{References}

Andrews, C. J. 2000. "Diffusion Pathways for Electricity Deregulation.” Publius: The Journal of Federalism 30(3): 1734.

Ardoin, P. J., Grady, D. 2006. "The Politics of Electricity Restructuring across the American States: Power Failure and Policy Failure." State \& Local Government Review 38(3): 165-175.

Balla, Steven J. 2001. "Interstate Professional Associations and the Diffusion of Policy Innovations." American Politics Research 39: 221-45.

Berry, William D., Richard C. Fording, Evan J. Ringquist, Russell L. Hanson, and Carl E. Klarner. 2010. "Measuring Citizen and Government Ideology in the U.S. States: A Re-appraisal." State Politics \& Policy Quarterly 10(2): 117 -135. Data through 2008 updated online at $\leq$ http://rcfording.wordpress.com/stateideology-data/>; retrieved January 19, 2011.

Boehmke, F. J., \& Witmer, R. 2004. "Disentangling diffusion: The effects of social learning and economic competition on state policy innovation and expansion." Political Research Quarterly 57(1): 39-51.

Boehmke, Frederick J. "Policy Emulation or Policy Convergence? Potential Ambiguities in the Dyadic Event History Approach to State Policy Emulation.” The Journal of Politics 71(3): 1125-1140.

Boushey, Graeme. 2010. Policy Diffusion Dynamics in America. New York, NY: Cambridge University Press.

Carley, Sanya, and Chris J. Miller. 2012. "Regulatory Stringency and Policy Drivers: A Reassessment of Renewable Portfolio Standards." Policy Studies Journal 40(4): 730-756.

Carley, Sanya, Nicholson-Crotty, Sean, Miller, Chris. 2016. "Adoption, Reinvention, and Amendment of Renewable Portfolio Standards in the American States." Journal of Public Policy 40(4): 730-756.

Chandler, Jess. 2009. “Trendy Solutions: Why do States Adopt Sustainable Energy Portfolio Standards?” Energy Policy 37(8): 3274-3281.

Desmarais, B. A., Harden, J. J., \& Boehmke, F. J. 2015. "Persistent Policy Pathways: Inferring Diffusion Networks in the American States.” American Political Science Review 109(02), 392-406.

Gilardi, Fabrizio. 2012. "Transnational Diffusion: Norms, Ideas, and Policies.” Handbook of International Relations, $2^{\text {nd }} \mathrm{Ed}$., Ch. 18. Thousand Oaks, CA: Sage Publications.

Gilardi, Fabrizio, and Katharina Füglister. 2008. "Empirical Modeling of Policy Diffusion in Federal States: The Dyadic Approach.” Swiss Political Science Review 14(3): 413-450.

Gray, Virginia. 1973. Innovation in the States: A Diffusion Study. American Political Science Review 67:1174-85.

Grossback, Lawrence J., Sean Nicholson-Crotty, and David A. M. Peterson. 2004. "Ideology and Learning in Policy Diffusion." American Politics Research 32(5):521-545.

Haider-Markel, Donald P. 2001. "Policy Diffusion as a Geographical Expansion of the Scope of Political Conflict: Same-Sex Marriage Bans in the 1990s.” State Politics and Policy Quarterly 1:5-26.

Huang, Ming-Yuan, Janaki R.R. Alavalapati, Douglas R. Carter, and Matthew H. Langholtz. 2007. "Is the Choice of Renewable Portfolio Standards Random?” Energy Policy 35(11): 5571-5575. 
Karch, Andrew. 2007. Democratic Laboratories: Policy Diffusion among the American States. Ann Arbor: University of Michigan Press.

Lyon, Thomas P., and Haitao Yin. 2010. "Why Do States Adopt Renewable Portfolio Standards?: An Empirical Investigation." The Energy Journal 31(3): 133-157.

Makse, Todd, and Craig Volden. 2011. "The Role of Policy Attributes in the Diffusion of Innovations.” Journal of Politics 73:108-24.

Matisoff, Daniel C. 2008. "The Adoption of State Climate Change Policies and Renewable Portfolio Standards: Regional Diffusion or Internal Determinants?” Review of Policy Research 25(6): 527-546.

Matisoff, Daniel C., and Jason Edwards. 2014. "Kindred Spirits or Intergovernmental Competition? The Innovation and Diffusion of Energy Policies in the American States (1990-2008)." Environmental Politics 23(5): 795-817.

Meseguer, C. 2005. "Policy learning, policy diffusion, and the making of a new order." The Annals of the American Academy of Political and Social Science, 598(1), 67-82.

Mintrom, Michael, and Sandra Vergari. 1998. "Policy Networks and Innovation Diffusion: The Case of Education Reform.” Journal of Politics 60:126-148.

National Renewable Energy Laboratory. 1991. Solar Radiation Data Manual for Flat-Plate and Concentrating Collectors. Available at <http://rredc.nrel.gov/solar/pubs/redbook/> Accessed January 3, 2008.

NC Clean Energy Technology Center. 2015. Database of State Incentives for Renewables \& Efficiency (DSIRE). Available at <http://www.dsireusa.org>. Last accessed November, 2015.

Nicholson-Crotty, Sean. 2009. "The Politics of Diffusion: Public Policy in the American States." The Journal of Politics 71 (1): 192-205.

Nicholson-Crotty, Sean, Carley, Sanya. 2015. "Effectiveness, Implementation Capacity, and Policy Diffusion: Or, 'Can We Make that Work for Us?" State Politics and Policy Quarterly.

Rogers, Everett M. 1995. Diffusion of Innovations. 4th ed. New York: The Free Press.

Schaffer, Lena Maria, and Thomas Bernauer. 2014. "Explaining Government Choices for Promoting Renewable Energy." Energy Policy 68: 15-27.

Shipan, Charles R., and Craig Volden. 2008. "The Mechanisms of Policy Diffusion.” American Journal of Political Science 52(4): 840-857.

Tews, Kerstin, Per-Olof Busch, and Helge Jörgens. 2003. "The Diffusion of New Environmental Policy Instruments.” European Journal of Political Research 42(4): 569-600.

U.S. Department of Energy. 2011. Energy Efficiency and Renewable Energy: Wind Powering America. Available online at $<$ http://www.windpoweringamerica.gov/wind_maps.asp>. Retrieved September 21, 2011.

U.S. Energy Information Administration, 2010. Status of Electricity Restructuring by State. Available here http://www.eia.gov/electricity/policies/restructuring/restructure elect.html. Last accessed December, 2015. 
U.S. Environmental Protection Agency. 2015. "State CO2 Emissions from Fossil Fuel Combustion.” Available at <http://www.epa.gov/statelocalclimate/resources/state_energyco2inv.html>. Last accessed December, 2015.

Volden, Craig. 2002. "The Politics of Competitive Federalism: A Race to the Bottom in Welfare Benefits?" American Journal of Political Science 46: 352-363.

Volden, Craig. 2006. "States as Policy Laboratories: Emulating Success in the Children's Health Insurance Program.” American Journal of Political Science 50(2): 294-312.

Volden, Craig, Michael Ting, Daniel Carpenter. 2008. “A Formal Model of Learning and Policy Diffusion.” American Political Science Review 102: 319-332.

Walker, Jack L. 1969. “The Diffusion of Innovations Among the American States.” American Political Science Review 63(3): 880-899.

Weyland, K. G. 2004. Learning from foreign models in Latin American policy reform. Johns Hopkins University Press.

Weyland, K. G. 2005. “Theories of policy diffusion: lessons from Latin American pension reform.” World politics $57(2), 262-295$.

Yi, Hongtao, and Richard C. Feiock. 2012. "Policy Tool Interactions and the Adoption of State Renewable Portfolio Standards." Review of Policy Research 29(2): 193-206. 
Table 1. Types of relationships reported by respondents and the corresponding percentage of total responses

\begin{tabular}{lcc}
\hline Types of Relationship & Number of responses & Percent of total responses \\
\hline Regional states & 206 & $17.17 \%$ \\
Similar energy resources & 186 & $15.50 \%$ \\
Neighbor & 177 & $14.75 \%$ \\
Attend same conference or meetings & 140 & $11.67 \%$ \\
Traditionally had a relationship with that state & 119 & $9.92 \%$ \\
Shared government or citizen ideology & 110 & $9.17 \%$ \\
Shared interest group influence & 87 & $7.25 \%$ \\
Similar economic make-up & 86 & $7.17 \%$ \\
Other & & $0.00 \%$ \\
$\quad$ State identified is recognized as a 'leader' & 46 & $3.83 \%$ \\
Policy experimentation & 25 & $2.08 \%$ \\
Shared influence by the same nonprofits (e.g., & 11 & $0.92 \%$ \\
RGGI*) & & \\
$\quad$ Other - Unspecified & 7 & $0.58 \%$ \\
Total & 1200 & \\
\hline
\end{tabular}

* RGGI is an acronym for the Regional Greenhouse Gas Initiative 
Table 2. Survey Response Information and Inter- and Intra-Category Overlap

\begin{tabular}{|c|c|c|c|c|c|c|c|c|c|c|c|}
\hline State & $\begin{array}{l}\text { Number } \\
\text { Respondents }\end{array}$ & $\begin{array}{l}\text { Number } \\
\text { State } \\
\text { Agency } \\
\text { Respondents }\end{array}$ & $\begin{array}{l}\text { Number } \\
\text { Legislative } \\
\text { Respondents }\end{array}$ & $\begin{array}{l}\text { Average } \\
\text { Number Peer } \\
\text { Connections: } \\
\text { State Officials }\end{array}$ & $\begin{array}{l}\text { Average } \\
\text { Number Peer } \\
\text { Connections: } \\
\text { State } \\
\text { Legislators }\end{array}$ & $\begin{array}{l}\text { Total } \\
\text { Reported } \\
\text { Connections } \\
\text { (Includes } \\
\text { Overlapping } \\
\text { Responses) } \\
\end{array}$ & $\begin{array}{l}\text { Total } \\
\text { Reported Peer } \\
\text { Connections } \\
\text { (Excludes } \\
\text { Overlapping } \\
\text { Responses) } \\
\end{array}$ & $\begin{array}{l}\text { Percent Inter- } \\
\text { Respondent } \\
\text { Category Overlap } \\
\text { (Number Overlapping } \\
\text { Reported States across } \\
\text { Categories/Total } \\
\text { Responses) } \\
\end{array}$ & $\begin{array}{l}\text { Percent } \\
\text { Intra- } \\
\text { Respondent } \\
\text { Category } \\
\text { Overlap: } \\
\text { State Off. } \\
\end{array}$ & $\begin{array}{l}\text { Percent } \\
\text { Intra- } \\
\text { Responden } \\
\text { t Category } \\
\text { Overlap: } \\
\text { State Leg. }\end{array}$ & $\begin{array}{l}\text { Overall Measure } \\
\text { of Overlap (Number } \\
\text { Overlapping Reported } \\
\text { States/Total Responses) }\end{array}$ \\
\hline Alaska & 3 & 2 & 1 & 7 & 0 & 12 & 11 & $0.0 \%$ & $15.4 \%$ & & $0.0 \%$ \\
\hline Arkansas & 1 & 0 & 1 & & 0 & 0 & 0 & & & & \\
\hline California & 1 & 1 & 0 & 4 & 0 & 4 & 4 & & & & \\
\hline Colorado & 5 & 3 & 2 & 7.3 & 4 & 27 & 17 & $40.7 \%$ & $63.2 \%$ & $25.0 \%$ & $77.8 \%$ \\
\hline Connecticut & 8 & 4 & 4 & 5.75 & 1.75 & 29 & 13 & $55.2 \%$ & $86.4 \%$ & $57.1 \%$ & $79.3 \%$ \\
\hline Delaware & 4 & 4 & 0 & 6.25 & & 23 & 11 & & $82.6 \%$ & & \\
\hline Florida & 1 & 1 & 0 & 8 & & 8 & 8 & & & & \\
\hline Georgia & 4 & 1 & 3 & & 1.67 & 10 & 10 & & & $0.0 \%$ & \\
\hline Hawaii & 2 & 1 & 1 & 5 & 10 & 15 & 13 & $26.7 \%$ & & & $26.7 \%$ \\
\hline Idaho & 2 & 1 & 1 & 6 & 1 & 7 & 6 & $28.6 \%$ & & & $28.6 \%$ \\
\hline Illinois & 2 & 1 & 1 & 3 & 1 & 4 & 3 & $50.0 \%$ & & & $50.0 \%$ \\
\hline Indiana & 3 & 1 & 2 & 0 & 3.5 & 4 & 3 & $0.0 \%$ & & $50.0 \%$ & $50.0 \%$ \\
\hline Iowa & 3 & 2 & 1 & 4 & 0 & 5 & 5 & $0.0 \%$ & $0.0 \%$ & & $0.0 \%$ \\
\hline Kansas & 2 & 0 & 2 & & 2.5 & 5 & 5 & & & $0.0 \%$ & $0.0 \%$ \\
\hline Kentucky & 2 & 2 & 0 & 4 & & 8 & 6 & & $50.0 \%$ & & $50.0 \%$ \\
\hline Louisiana & 1 & 0 & 1 & & 0 & 0 & 0 & & & & \\
\hline Maine & 5 & 4 & 1 & 3.75 & 6 & 17 & 8 & $88.2 \%$ & $75.0 \%$ & & $88.2 \%$ \\
\hline Mass. & 2 & 2 & 0 & 7 & & 12 & 8 & & $66.7 \%$ & & $66.7 \%$ \\
\hline Michigan & 6 & 5 & 1 & 2.6 & 3 & 16 & 9 & $43.8 \%$ & $61.5 \%$ & & $68.8 \%$ \\
\hline Minnesota & 1 & 1 & 0 & 4 & & 4 & 4 & & & & \\
\hline Missouri & 3 & 2 & 1 & 3 & 7 & 13 & 11 & $30.8 \%$ & $0.0 \%$ & $0.0 \%$ & $30.8 \%$ \\
\hline Montana & 8 & 2 & 6 & 1.5 & 2.17 & 16 & 8 & $31.3 \%$ & $0.0 \%$ & $69.2 \%$ & $75.0 \%$ \\
\hline Nebraska & 3 & 2 & 1 & 4 & 0 & 8 & 5 & $0.0 \%$ & $75.0 \%$ & & $75.0 \%$ \\
\hline Nevada & 1 & 1 & 0 & 7 & & 7 & 7 & & & & \\
\hline New & 4 & 1 & 3 & 0 & 2.67 & 7 & 5 & $0.0 \%$ & & $57.1 \%$ & $57.1 \%$ \\
\hline \multicolumn{12}{|l|}{ Hampshire } \\
\hline $\begin{array}{l}\text { New Jersey } \\
\text { New }\end{array}$ & 1 & 0 & 1 & & 1 & 1 & $\begin{array}{l}1 \\
5\end{array}$ & & & & \\
\hline \multicolumn{12}{|l|}{ Mexico } \\
\hline New York & 2 & 2 & 0 & 4 & & 8 & 6 & & $50.0 \%$ & & $50.0 \%$ \\
\hline $\begin{array}{l}\text { North } \\
\text { Carolina }\end{array}$ & \multicolumn{11}{|c|}{ Carolina } \\
\hline N. Dakota & 1 & 1 & 0 & 1 & & 1 & 1 & & & & \\
\hline Ohio & 1 & 1 & 0 & 5 & & 5 & 5 & & & & \\
\hline Oklahoma & 1 & 0 & 1 & & 0 & 0 & 0 & & & & \\
\hline Oregon & 2 & 1 & 1 & 0 & 2 & 2 & 2 & $0.0 \%$ & & & $0.0 \%$ \\
\hline Tennessee & 2 & 2 & 0 & 5 & & 9 & 9 & & $0.0 \%$ & & \\
\hline Texas & 1 & 0 & 1 & & 0 & 0 & 0 & & & & \\
\hline Utah & 4 & 2 & 2 & 2.5 & 5 & 13 & 11 & $23.1 \%$ & $0.0 \%$ & $60.0 \%$ & $53.8 \%$ \\
\hline Vermont & 2 & 1 & 1 & 7 & 4 & 9 & 6 & $66.7 \%$ & & & $66.7 \%$ \\
\hline Virginia & 2 & 2 & 0 & 2 & & 4 & 4 & & $0.0 \%$ & & \\
\hline Washington & 4 & 3 & 1 & 2.3 & 1 & 8 & 5 & $37.5 \%$ & $57.1 \%$ & & $62.5 \%$ \\
\hline West & 2 & 1 & 1 & 5 & 1 & 6 & 5 & $33.3 \%$ & & & $33.3 \%$ \\
\hline \multicolumn{12}{|l|}{ Virginia } \\
\hline Wisconsin & 2 & 2 & 0 & 4.5 & & 9 & 7 & & $44.4 \%$ & & $44.4 \%$ \\
\hline Wyoming & 5 & 0 & 5 & & 1.6 & 8 & 4 & & & $75.0 \%$ & $75.0 \%$ \\
\hline Total & 112 & 64 & 48 & & & 352 & 252 & & & & \\
\hline Average & 2.7 & 1.5 & 1.1 & 4.0 & 2.2 & 8.4 & 6.0 & $30.6 \%$ & $40.4 \%$ & $39.4 \%$ & $48.7 \%$ \\
\hline
\end{tabular}




\section{Table 3. Regression Results in which the Dependent Variable is RPS Adoption}

\begin{tabular}{|c|c|c|c|c|c|c|c|c|c|c|c|}
\hline & Base Model & Model 1 & Model 2 & Model 3 & Model 4 & Model 5 & Model 6 & Model 7 & Model 8 & (9) & (10-Any reason) \\
\hline Ideological Distance ij & $\begin{array}{l}-0.00533 * * * \\
(0.000772)\end{array}$ & $\begin{array}{l}-0.00524 * * * \\
(0.000773)\end{array}$ & $\begin{array}{l}-0.00521 * * * \\
(0.000772)\end{array}$ & $\begin{array}{l}-0.00494 * * * \\
(0.000771)\end{array}$ & $\begin{array}{l}-0.00528 * * * \\
(0.000773)\end{array}$ & $\begin{array}{l}-0.00515 * * * \\
(0.000774)\end{array}$ & $\begin{array}{l}-0.00514 * * * \\
(0.000774)\end{array}$ & $\begin{array}{l}-0.00522 * * * \\
(0.000772)\end{array}$ & $\begin{array}{l}-0.00527 * * * \\
(0.000772)\end{array}$ & $\begin{array}{l}-0.00518 * * * \\
(0.000771)\end{array}$ & $\begin{array}{l}-0.00512 * * * \\
(0.000771)\end{array}$ \\
\hline Neighbors $_{i j}$ & $\begin{array}{l}0.466^{* * *} \\
(0.0561)\end{array}$ & $\begin{array}{l}0.449 * * * \\
(0.0578)\end{array}$ & $\begin{array}{l}0.435^{* * *} \\
(0.0590)\end{array}$ & $\begin{array}{l}0.415^{* * *} \\
(0.0575)\end{array}$ & $\begin{array}{l}0.442^{* * *} \\
(0.0613)\end{array}$ & $\begin{array}{l}0.420^{* * *} \\
(0.0587)\end{array}$ & $\begin{array}{l}0.415^{* * *} \\
(0.0581)\end{array}$ & $\begin{array}{l}0.446 * * * \\
(0.0573)\end{array}$ & $\begin{array}{l}0.448^{* * *} \\
(0.0574)\end{array}$ & $\begin{array}{l}0.453 * * * \\
(0.0563)\end{array}$ & $\begin{array}{l}0.410^{* * *} \\
(0.0596)\end{array}$ \\
\hline Shared Economic Conditionsij & & $\begin{array}{l}0.179 \\
(0.124)\end{array}$ & & & & & & & & & \\
\hline Shared Energy & & & & & & & & & & & \\
\hline Resources/Markets $\mathrm{ij}_{\mathrm{ij}}$ & & & $\begin{array}{l}0.186^{*} \\
(0.0884)\end{array}$ & & & & & & & & \\
\hline Shared Ideologyij & & & & $\begin{array}{l}0.520^{* * *} \\
(0.100)\end{array}$ & & & & & & & \\
\hline Neighboring Statesij & & & & & $\begin{array}{l}0.111 \\
(0.0993)\end{array}$ & & & & & & \\
\hline Regional Statesij & & & & & & $\begin{array}{l}0.270 * * \\
(0.0889)\end{array}$ & & & & & \\
\hline Traditionally had a & & & & & & & & & & & \\
\hline Relationshipij & & & & & & & $\begin{array}{l}0.369 * * * \\
(0.101)\end{array}$ & & & & \\
\hline Similar Interest Group & & & & & & & & & & & \\
\hline Influence $_{i j}$ & & & & & & & & $\begin{array}{l}0.251^{*} \\
(0.125)\end{array}$ & & & \\
\hline Regularly Attend Same & & & & & & & & & & & \\
\hline Conferences ${ }_{i j}$ & & & & & & & & & $\begin{array}{l}0.162 \\
(0.0948)\end{array}$ & & \\
\hline Other $_{i j}$ & & & & & & & & & & $\begin{array}{l}0.384^{* * *} \\
(0.116)\end{array}$ & \\
\hline Any "Non-traditional” Reason & & & & & & & & & & & $\begin{array}{l}0.235^{* *} \\
(0.0710)\end{array}$ \\
\hline Electricity Deregulation $_{i}$ & $\begin{array}{l}0.151^{* *} \\
(0.0509)\end{array}$ & $\begin{array}{l}0.151^{* *} \\
(0.0508)\end{array}$ & $\begin{array}{l}0.154^{* *} \\
(0.0508)\end{array}$ & $\begin{array}{l}0.152^{* *} \\
(0.0510)\end{array}$ & $\begin{array}{l}0.153 * * \\
(0.0507)\end{array}$ & $\begin{array}{l}0.159 * * \\
(0.0507)\end{array}$ & $\begin{array}{l}0.157^{* *} \\
(0.0507)\end{array}$ & $\begin{array}{l}0.152^{* *} \\
(0.0509)\end{array}$ & $\begin{array}{l}0.159 * * \\
(0.0507)\end{array}$ & $\begin{array}{l}0.156^{* *} \\
(0.0507)\end{array}$ & $\begin{array}{l}0.166^{* *} \\
(0.0506)\end{array}$ \\
\hline Renewable Energy Potential ${ }_{i}$ & $\begin{array}{l}0.000370 * * * \\
(0.0000963)\end{array}$ & $\begin{array}{l}0.000369 * * * \\
(0.0000965)\end{array}$ & $\begin{array}{l}0.000364^{* * *} \\
(0.0000968)\end{array}$ & $\begin{array}{l}0.000370^{* * *} \\
(0.0000968)\end{array}$ & $\begin{array}{l}0.000375^{* * *} \\
(0.0000963)\end{array}$ & $\begin{array}{l}0.000371 * * * \\
(0.0000964)\end{array}$ & $\begin{array}{l}0.000377^{* * *} \\
(0.0000961)\end{array}$ & $\begin{array}{l}0.000373 * * * \\
(0.0000964)\end{array}$ & $\begin{array}{l}0.000366 * * * \\
(0.0000967)\end{array}$ & $\begin{array}{l}0.000360^{* * *} \\
(0.0000974)\end{array}$ & $\begin{array}{l}0.000368^{* * *} \\
(0.00009)\end{array}$ \\
\hline $\mathrm{CO}_{2}$ Per Capita & $\begin{array}{l}-0.000482^{* * * *} \\
(0.0000671)\end{array}$ & $\begin{array}{l}-0.000482 * * * \\
(0.0000673)\end{array}$ & $\begin{array}{l}-0.000481 * * * \\
(0.0000675)\end{array}$ & $\begin{array}{l}-0.000465^{* * *} \\
(0.0000676)\end{array}$ & $\begin{array}{l}-0.000481 * * * \\
(0.0000672)\end{array}$ & $\begin{array}{l}-0.000474 * * * \\
(0.0000674)\end{array}$ & $\begin{array}{l}-0.000476 * * * \\
(0.0000675)\end{array}$ & $\begin{array}{l}-0.000474 * * * \\
(0.0000672)\end{array}$ & $\begin{array}{l}-0.000480 * * * \\
(0.0000674)\end{array}$ & $\begin{array}{l}-0.000479 * * * \\
(0.0000674)\end{array}$ & $\begin{array}{c}-0.00047 * * * \\
(0.0000676)\end{array}$ \\
\hline Citizen ideologyi & $\begin{array}{l}0.0199 * * * \\
(0.00179)\end{array}$ & $\begin{array}{l}0.0198 * * * \\
(0.00180)\end{array}$ & $\begin{array}{l}0.0197 * * * \\
(0.00179)\end{array}$ & $\begin{array}{l}0.0196^{* * * *} \\
(0.00180)\end{array}$ & $\begin{array}{l}0.0199 * * * \\
(0.00179)\end{array}$ & $\begin{array}{l}0.0198^{* * *} \\
(0.00179)\end{array}$ & $\begin{array}{l}0.0200 * * * \\
(0.00179)\end{array}$ & $\begin{array}{l}0.0198 * * * \\
(0.00179)\end{array}$ & $\begin{array}{l}0.0198^{* * *} \\
(0.00179)\end{array}$ & $\begin{array}{l}0.0197 * * * \\
(0.00180)\end{array}$ & $\begin{array}{l}0.0198^{* * *} \\
(0.00179)\end{array}$ \\
\hline Government Ideologyi & $\begin{array}{l}0.00407 * * * \\
(0.000778)\end{array}$ & $\begin{array}{l}0.00405^{* * *} \\
(0.000778)\end{array}$ & $\begin{array}{l}0.00401 * * * \\
(0.000778)\end{array}$ & $\begin{array}{l}0.00403 * * * \\
(0.000780)\end{array}$ & $\begin{array}{l}0.00405^{* * *} \\
(0.000778)\end{array}$ & $\begin{array}{l}0.00397 * * * \\
(0.000779)\end{array}$ & $\begin{array}{l}0.00396 * * * \\
(0.000778)\end{array}$ & $\begin{array}{l}0.00410^{* * *} \\
(0.000780)\end{array}$ & $\begin{array}{l}0.00405^{* * *} \\
(0.000779)\end{array}$ & $\begin{array}{l}0.00404 * * * \\
(0.000779)\end{array}$ & $\begin{array}{l}0.00404 * * * \\
(0.000781)\end{array}$ \\
\hline${\text { Electricity } \text { Price }_{i}}$ & $\begin{array}{l}-0.0160 * \\
(0.00764)\end{array}$ & $\begin{array}{l}-0.0159 * \\
(0.00765)\end{array}$ & $\begin{array}{l}-0.0161 * \\
(0.00765)\end{array}$ & $\begin{array}{l}-0.0164 * \\
(0.00765)\end{array}$ & $\begin{array}{l}-0.0162 * \\
(0.00761)\end{array}$ & $\begin{array}{l}-0.0168^{*} \\
(0.00763)\end{array}$ & $\begin{array}{l}-0.0183^{*} \\
(0.00766)\end{array}$ & $\begin{array}{l}-0.0161 * \\
(0.00765)\end{array}$ & $\begin{array}{l}-0.0170^{*} \\
(0.00762)\end{array}$ & $\begin{array}{l}-0.0175^{*} \\
(0.00763)\end{array}$ & $\begin{array}{l}-0.0178^{*} \\
(0.00762)\end{array}$ \\
\hline Constant & $\begin{array}{l}1206.5^{* * *} \\
(141.2)\end{array}$ & $\begin{array}{l}1205.4^{* * *} \\
(141.4)\end{array}$ & $\begin{array}{l}1209.9^{* * *} \\
(141.7)\end{array}$ & $\begin{array}{l}1193.9^{* * *} \\
(144.0)\end{array}$ & $\begin{array}{l}1209.1^{\text {*** }} \\
(141.1)\end{array}$ & $\begin{array}{l}1213.1^{\text {*** }} \\
(142.0)\end{array}$ & $\begin{array}{l}1222.9^{* * *} \\
(142.4)\end{array}$ & $\begin{array}{l}1196.3^{* * *} \\
(141.8)\end{array}$ & $\begin{array}{l}1218.3^{* * *} \\
(141.2)\end{array}$ & $\begin{array}{l}1207.4 \text { *** } \\
(142.8)\end{array}$ & $\begin{array}{l}1218.3^{* * *} \\
(141.8)\end{array}$ \\
\hline $\mathrm{N}$ & 20805 & 20805 & 20805 & 20805 & 20805 & 20805 & 20805 & 20805 & 20805 & 20805 & 20805 \\
\hline
\end{tabular}

splines of time. 
Table 4. Regression Results in which the Dependent Variable is Electricity Deregulation Adoption

\begin{tabular}{|c|c|c|c|c|c|c|c|c|c|c|c|}
\hline & Base & (1) & (2) & (3) & (4) & $(5)$ & (6) & (7) & (8) & (9) & $(10-$ Any reason $)$ \\
\hline Ideological Distance ij & $\begin{array}{l}-0.00444 * * * \\
(0.000953)\end{array}$ & $\begin{array}{l}-0.00420^{* * *} \\
(0.000951)\end{array}$ & $\begin{array}{l}-0.00402^{* * *} \\
(0.000950)\end{array}$ & $\begin{array}{c}-0.00392 * * * \\
(0.000944)\end{array}$ & $\begin{array}{c}-0.00436 \text { *** } \\
(0.000951)\end{array}$ & $\begin{array}{c}-0.00405^{* * *} \\
(0.000946)\end{array}$ & $\begin{array}{c}-0.00404^{* * *} \\
(0.000949)\end{array}$ & $\begin{array}{l}-0.00406^{* * *} \\
(0.000949)\end{array}$ & $\begin{array}{l}-0.00435^{* * *} \\
(0.000949)\end{array}$ & $\begin{array}{l}-0.00433 * * * \\
(0.000954)\end{array}$ & $\begin{array}{l}-0.0041 * * * \\
(0.00095)\end{array}$ \\
\hline Neighbors $_{i j}$ & $\begin{array}{l}0.424 * * * \\
(0.0780)\end{array}$ & $\begin{array}{l}0.394 * * * \\
(0.0805)\end{array}$ & $\begin{array}{l}0.359 * * * \\
(0.0817)\end{array}$ & $\begin{array}{l}0.375^{* * *} \\
(0.0804)\end{array}$ & $\begin{array}{l}0.403^{* * *} \\
(0.0848)\end{array}$ & $\begin{array}{l}0.369^{* * *} \\
(0.0815)\end{array}$ & $\begin{array}{l}0.366 * * * \\
(0.0813)\end{array}$ & $\begin{array}{l}0.388^{* * *} \\
(0.0795)\end{array}$ & $\begin{array}{l}0.408^{* * *} \\
(0.0794)\end{array}$ & $\begin{array}{l}0.415^{* * *} \\
(0.0786)\end{array}$ & $\begin{array}{l}0.378^{* * *} \\
(0.0824)\end{array}$ \\
\hline Shared Economic Conditions & & $\begin{array}{l}0.332^{\wedge} \\
(0.187)\end{array}$ & & & & & & & & & \\
\hline Shared Energy Resources/Markets & & & $\begin{array}{l}0.406^{* *} \\
(0.133)\end{array}$ & & & & & & & & \\
\hline Shared Ideology & & & & $\begin{array}{l}0.438^{* *} \\
(0.140)\end{array}$ & & & & & & & \\
\hline Neighboring States & & & & & $\begin{array}{l}0.104 \\
(0.165)\end{array}$ & & & & & & \\
\hline Regional States & & & & & & $\begin{array}{l}0.317^{*} \\
(0.131)\end{array}$ & & & & & \\
\hline Traditionally had a Relationship & & & & & & & $\begin{array}{l}0.466 \text { ** } \\
(0.153)\end{array}$ & & & & \\
\hline Similar Interest Group Influence & & & & & & & & $\begin{array}{l}0.499 * * \\
(0.169)\end{array}$ & & & \\
\hline Regularly Attend Same Conferences & & & & & & & & & $\begin{array}{l}0.149 \\
(0.147)\end{array}$ & & \\
\hline Other & & & & & & & & & & $\begin{array}{l}0.203 \\
(0.171)\end{array}$ & \\
\hline Any "Nontraditional" Reason & & & & & & & & & & & $\begin{array}{l}0.200^{* *} \\
(0.102)\end{array}$ \\
\hline Renewable Energy Potentiali & $\begin{array}{l}0.000211 \\
(0.000124)\end{array}$ & $\begin{array}{l}0.000220 \\
(0.000124)\end{array}$ & $\begin{array}{l}0.000232 \\
(0.000123)\end{array}$ & $\begin{array}{l}0.000204 \\
(0.000125)\end{array}$ & $\begin{array}{l}0.000216 \\
(0.000125)\end{array}$ & $\begin{array}{l}0.000220 \\
(0.000124)\end{array}$ & $\begin{array}{l}0.000213 \\
(0.000125)\end{array}$ & $\begin{array}{l}0.000233 \\
(0.000124)\end{array}$ & $\begin{array}{l}0.000214 \\
(0.000124)\end{array}$ & $\begin{array}{l}0.000214 \\
(0.000124)\end{array}$ & $\begin{array}{l}0.000220 \\
(0.000124)\end{array}$ \\
\hline $\mathrm{CO}_{2}$ Per Capita & $\begin{array}{l}-0.00122^{* * *} \\
(0.000117)\end{array}$ & $\begin{array}{c}-0.00121 \text { *** } \\
(0.000116)\end{array}$ & $\begin{array}{l}-0.00121 \text { *** } \\
(0.000115)\end{array}$ & $\begin{array}{c}-0.00117 * * * \\
(0.000115)\end{array}$ & $\begin{array}{l}-0.00122 * * * \\
(0.000116)\end{array}$ & $\begin{array}{c}-0.00120^{* * *} \\
(0.000115)\end{array}$ & $\begin{array}{c}-0.00119 * * * \\
(0.000116)\end{array}$ & $\begin{array}{l}-0.00119 * * * \\
(0.000116)\end{array}$ & $\begin{array}{l}-0.00122 * * * \\
(0.000117)\end{array}$ & $\begin{array}{l}-0.00123 * * * \\
(0.000116)\end{array}$ & $\begin{array}{l}-0.00121 * * * \\
(0.000116)\end{array}$ \\
\hline Citizen ideologyi & $\begin{array}{l}0.00627 * \\
(0.00268)\end{array}$ & $\begin{array}{l}0.00572 * \\
(0.00269)\end{array}$ & $\begin{array}{l}0.00537^{*} \\
(0.00269)\end{array}$ & $\begin{array}{l}0.00563 * \\
(0.00269)\end{array}$ & $\begin{array}{l}0.00617 * \\
(0.00268)\end{array}$ & $\begin{array}{l}0.00590 * \\
(0.00268)\end{array}$ & $\begin{array}{l}0.00597 * \\
(0.00267)\end{array}$ & $\begin{array}{l}0.00590^{*} \\
(0.00267)\end{array}$ & $\begin{array}{l}0.00595^{*} \\
(0.00267)\end{array}$ & $\begin{array}{l}0.00602 * \\
(0.00267)\end{array}$ & $\begin{array}{l}0.00592 * \\
(0.00268)\end{array}$ \\
\hline Government Ideologyi & $\begin{array}{l}0.00154 \\
(0.000919)\end{array}$ & $\begin{array}{l}0.00154 \\
(0.000920)\end{array}$ & $\begin{array}{l}0.00159 \\
(0.000931)\end{array}$ & $\begin{array}{l}0.00147 \\
(0.000925)\end{array}$ & $\begin{array}{l}0.00155 \\
(0.000921)\end{array}$ & $\begin{array}{l}0.00150 \\
(0.000924)\end{array}$ & $\begin{array}{l}0.00141 \\
(0.000926)\end{array}$ & $\begin{array}{l}0.00170 \\
(0.000934)\end{array}$ & $\begin{array}{l}0.00156 \\
(0.000923)\end{array}$ & $\begin{array}{l}0.00156 \\
(0.000917)\end{array}$ & $\begin{array}{l}0.00162 \\
(0.000921)\end{array}$ \\
\hline Electricity Price $_{i}$ & $\begin{array}{l}-0.00143 \\
(0.0103)\end{array}$ & $\begin{array}{l}-0.000541 \\
(0.0103)\end{array}$ & $\begin{array}{l}-0.00226 \\
(0.0102)\end{array}$ & $\begin{array}{l}-0.00258 \\
(0.0103)\end{array}$ & $\begin{array}{l}-0.00194 \\
(0.0102)\end{array}$ & $\begin{array}{l}-0.00295 \\
(0.0103)\end{array}$ & $\begin{array}{l}-0.00424 \\
(0.0104)\end{array}$ & $\begin{array}{l}-0.00173 \\
(0.0103)\end{array}$ & $\begin{array}{l}-0.00164 \\
(0.0103)\end{array}$ & $\begin{array}{l}-0.00288 \\
(0.0105)\end{array}$ & $\begin{array}{l}-0.00335 \\
(0.0103)\end{array}$ \\
\hline Intercept & $\begin{array}{l}-395.9 * * * \\
(30.22)\end{array}$ & $\begin{array}{l}-401.8^{* * *} \\
(30.48)\end{array}$ & $\begin{array}{l}-412.4^{* * *} \\
(30.42)\end{array}$ & $\begin{array}{l}-415.2^{* * *} \\
(30.62)\end{array}$ & $\begin{array}{l}-397.4^{* * *} \\
(30.19)\end{array}$ & $\begin{array}{l}-405.8^{* * *} \\
(30.39)\end{array}$ & $\begin{array}{l}-410.3^{* * *} \\
(30.60)\end{array}$ & $\begin{array}{l}-407.0^{* * *} \\
(30.30)\end{array}$ & $\begin{array}{l}-400.1 * * * \\
(30.11)\end{array}$ & $\begin{array}{l}-401.8^{* * *} \\
(29.94)\end{array}$ & $\begin{array}{l}-404.5^{* * *} \\
(30.08)\end{array}$ \\
\hline $\mathrm{N}$ & 17608 & 17608 & 17608 & 17608 & 17608 & 17608 & 17608 & 17608 & 17608 & 17608 & 17608 \\
\hline
\end{tabular}

Standard errors in parentheses ${ }^{\wedge} \mathrm{p}<0.1,{ }^{*} \mathrm{p}<0.05,{ }^{* *} \mathrm{p}<0.01,{ }^{* * *} \mathrm{p}<0.001$ 


\section{Appendix}

Table A1 Interactive effect of sharing a border and "having a traditional relationship" on the likelihood of adopting RPS

\begin{tabular}{|c|c|}
\hline Variable & Coef. (s.e.) \\
\hline \multirow[t]{2}{*}{ Ideological Distance ij } & $-0.00517 * * *$ \\
\hline & $(0.000772)$ \\
\hline \multirow[t]{2}{*}{ Neighbors $_{i j}$} & $0.480^{* * *}$ \\
\hline & $(0.0623)$ \\
\hline \multirow[t]{2}{*}{ Traditionally had a Relationship $\mathrm{p}_{\mathrm{ij}}$} & $0.553^{* * *}$ \\
\hline & $(0.121)$ \\
\hline \multirow[t]{2}{*}{ Neighbors $_{i j}{ }^{*}$ Tradiitonal Relationship ${ }_{i j}$} & $-0.542 * *$ \\
\hline & $(0.172)$ \\
\hline \multirow[t]{2}{*}{ Electricity Deregulation $_{\mathrm{i}}$} & $0.165^{* *}$ \\
\hline & $(0.0506)$ \\
\hline \multirow[t]{2}{*}{ Renewable Energy Potential ${ }_{i}$} & $0.000360^{* * *}$ \\
\hline & $(0.0000971)$ \\
\hline \multirow[t]{2}{*}{$\mathrm{CO}_{2}$ Per Capita } & $\begin{array}{l}- \\
0.000475^{* * *}\end{array}$ \\
\hline & $(0.0000673)$ \\
\hline \multirow[t]{2}{*}{ Citizen ideologyi } & $0.0198^{* * *}$ \\
\hline & $(0.00179)$ \\
\hline \multirow[t]{2}{*}{ Government Ideology $y_{i}$} & $0.00398^{* * *}$ \\
\hline & $(0.000781)$ \\
\hline \multirow[t]{2}{*}{${\text { Electricity } \text { Price }_{i}}$} & $-0.0178^{*}$ \\
\hline & $(0.00763)$ \\
\hline \multirow[t]{2}{*}{ Constant } & $1235.3^{* * *}$ \\
\hline & $(142.0)$ \\
\hline $\mathrm{N}$ & 20805 \\
\hline $\begin{array}{l}\text { Standard er } \\
\mathrm{p}<.001\end{array}$ & $1, *$ \\
\hline
\end{tabular}

